\title{
Policy Reform and Growth in Post-Soviet Russia
}

\author{
By: Daniel Berkowitz and David N. DeJong
}

William Davidson Working Paper Number 405

October 2001 


\title{
Policy Reform and Growth in Post-Soviet Russia
}

\author{
Daniel Berkowitz* and David N. DeJong \\ Department of Economics; University of Pittsburgh; Pittsburgh, PA 15260
}

Final Version: October 2001

\begin{abstract}
In pursuit of its transition from a command to a market economy, Russia has witnessed enormous regional differences in economic growth rates. Moreover, the implementation of economic reforms has also differed markedly across regions. We analyze whether regional differences in reform policies can account for regional differences in growth rates, and conclude that to a considerable degree, they can. Most notably, we find that regional differences in price liberalization policies exhibit a positive direct correspondence with growth. We also find that regional differences in large-scale privatization exhibit a positive correspondence with the regional formation of new legal enterprises, which in turn exhibits a strong positive correspondence with growth.
\end{abstract}

Keywords: New enterprise formation, privatization, price liberalization

JEL Codes: O4, P3, R1

Acknowledgments: We thank Anders Aslund, Gleb Bylov, Lev Freinkman, Yelena Borisovna Frolova, Clifford Gaddy, Evgeny Gavrilenkov, Timothy Heleniak, Alastair McAuley, Thomas Richardson, Randi Ryterman and especially Nina Chebotarieva for their help with the data used in this study. We also thank John McMillan, Peter Murrell, Harald Uhlig and two anonymous referees for many useful comments. For providing financial support, Berkowitz is indebted to the National Council for Soviet and East European Studies (under contracts \#807-09 and \#811-12); the National Science Foundation (under grant SBR-9730499); and the Center for Russian and East European Studies at the University of Pittsburgh. The usual caveat applies.

\footnotetext{
* Corresponding Author: E-Mail: dmberk@ pitt.edu, telephone: 412-648-7072, fax: 412-648-3011, Department of Economics, 4D10 W.W. Posvar Hall, Pittsburgh, PA 15260.
} 


\section{Introduction}

In pursuit of its transition from a command to a market economy, Russia has experienced enormous regional differences in economic growth rates. Over the period 1993:IV through 1997:IV, the 48 regions in Russia in which the capital city comprises at least $30 \%$ of the total regional population had annual average growth rates in real per capita income ranging from -9.0 to $15.7 \% .^{1}$ Moreover, the implementation of economic reforms following the breakup of the Soviet Union has also differed markedly across regions. For example, Magadan has aggressively pursued small- and large-enterprise privatization reforms, but has been slow to liberalize prices; the opposite is true in Moscow. And while Saratov and Kaliningrad have aggressively implemented both privatization and price-liberalization reforms, Ulyanovsk and the secessionist Republics of Bashkortostan and Tatarstan have done neither.

We analyze whether regional differences in the implementation of price-liberalization and privatization reform policies can account for regional differences in growth rates, and conclude that to a considerable degree, they can. Specifically, we find that regional differences in price-liberalization policies exhibit a positive direct correspondence with growth. We also find that regional differences in large-scale privatization reforms exhibit a positive correspondence with the regional formation of new legal enterprises, which in turn exhibits a strong positive correspondence with growth.

Ongoing literatures focus on the implementation of price-liberalization and privatization reforms in transition economies. Price liberalization is clearly important, since it enhances the efficiency with which resources are allocated, yet the speed at which liberalization reforms should be implemented is less clear (for a discussion of alternative viewpoints, see Roland, 2000,

\footnotetext{
${ }^{1}$ We analyze only 48 of Russia's 89 regions due to data constraints; see Section 2 for details.
} 
Ch. 6, and references therein). For example, Murphy, Shleifer and Vishny (1992) argue in favor of rapid implementation because gradual/partial implementation can create supply diversions that generate welfare losses. Alternatively, Lau, Qian and Roland (2000) show that gradual liberalization can also be effective in achieving transition, and note that China has experienced rapid growth in their transition even though they have only gradually liberalized prices.

Privatization reforms are also generally viewed as important, since state ownership can lead to inefficiencies resulting from excess employment, asset stripping, and corruption (e.g., see Shleifer and Vishny, 1994). However, Roland (2000) notes that managers of state-owned enterprises in transition economies have also succeeded in shedding excess labor and restructuring their operations to run more efficiently (Roland, 2000, Ch. 9, and references therein). Moreover, Carlin et al. (2001) examine 3,300 firms in 25 transition countries, and find that ownership per se has no significant impact on firm performance. Efficiency issues aside, privatization reforms are also potentially important due to their potential impact on new enterprise formation, which as Kornai (1990), McMillan (1997) and Berkowitz and DeJong (2001) emphasize, is an important growth engine in transition economies. For example, McMillan argues that by severing political connections from formerly state-owned enterprises, privatization can reduce or eliminate the incentive of local governments to use their tax and regulatory power against private enterprises in an effort to protect state-owned business interests. Privatization can thus potentially enhance regional private-business environments.

In the case of Russia, it is useful to distinguish between small- and large-scale privatization reforms. Privatization began in 1993 when all state-owned firms were allocated to the property funds of the federal government, and governments located in the regions (these include the primary regional government and subordinate local governments in cities, 
settlements, etc.). Local governments usually obtained control over small shops and stores operating predominately in trade and retail services; for the most part, these shops could be sold off for cash. The federal government obtained control over large enterprises in the manufacturing, communications, energy, and heavy industry sectors. With the varied cooperation of the regional governments in which these large enterprises were located, the federal government sold off ownership shares to insiders at a discount, and allowed limited groups of outside investors to buy ownership positions using vouchers (these were equity claims that the Russian federal government had issued just before privatizing). As with price-liberalization reforms, the extent of privatization activity has varied markedly across regions.

The impact of Russia's small- and large-scale privatization reforms on new enterprise formation is controversial. Boycko, Shlefier, and Vishny (1995) argue that revenues from small privatization provided an incentive for regional governments to support market-enhancing reforms, including the development of regulatory environments conducive to new enterprise formation. However, Friebel (1995) shows that there has been considerable insider self-dealing at the regional level in Russia: managers and well-connected members of the government often colluded either to gain control of privatized assets or to block local reform efforts. Black, Kraakman and Tarassova (2000) argue that large-scale privatization has led to insider selfdealing, and has produced a business climate characterized by excessive and arbitrary taxation, official corruption, and ubiquitous organized crime. However, large-scale privatization may have released a public demand for the enforcement of good regulations, because federally privatized enterprises are typically much larger than locally privatized firms, and therefore, more closely monitored by the public (Berkowitz and Holland, 2001). 
Given the importance of distinguishing between small- and large-scale privatization in the case of Russia, we measure both types of activity separately at the regional level. As noted, we find that large-scale privatization exhibits a positive correspondence with the regional formation of new legal enterprises, which in turn exhibits a strong positive correspondence with growth. In contrast, small-scale privatization exhibits a statistically and quantitatively weak correspondence with both growth and new enterprise formation, perhaps due in part to the insider self-dealing noted by Friebel (1995).

Complementary to our intra-national analysis, several empirical studies on transition in the Former Soviet Union and Eastern Europe focus on international patterns of policy reforms and economic growth. For example, see de Melo and Gelb (1996); de Melo, Denizer and Gelb (1996); Fisher, Sahay and Gel (1996); Sachs, (1997); and Selowsky and Martin (1997).

\section{Data Description}

Our data set includes regional measures of income growth, new enterprise formation, initial conditions and policy reforms. All eleven of Russia's geographic territories have regions included in the data set. There are 89 regions in Russia, including 21 republics, six krays, 49 oblasts, one autonomous oblast, ten autonomous okrugs, and two federal cities (Moscow and St. Petersburg). Ideally, we would work with data from all 89 regions. However, our regional price-liberalization measure is reported only at the capital-city level, and thus is not necessarily representative of the region as a whole. To minimize this problem, we limit our sample to 
regions in which the capital city comprises at least $30 \%$ of the total regional population. ${ }^{2}$ There $^{2}$ are 48 such regions in Russia; these regions, along with their geographic territories, are reported in Table 1.

\section{2a. Growth and New Enterprise Formation}

We use real per capita income data to measure growth in regional standards of living (GROWTH). Our measure of GROWTH is the annualized average growth rate between December of 1993 and 1997:IV of regional per capita money income, deflated by a regionallevel consumer price index (source: Goskomstat Rossii, 1993, 1994, 1995b, 1997, 1998). Our measure of new enterprise formation (NEWENT) is the number of small legally registered private enterprises per thousand inhabitants as of December 31, 1995 (source: Goskmostat Rossii, 1996). This measure approximates the regional "stock" of private small enterprises at that date, since regional governments typically require their enterprises to register on an annual basis. While employment ceilings that define small enterprises vary across industries, the typical small enterprise employs no more than 200 workers. These enterprises include privatized former state enterprises, spin-offs from privatized state enterprises, and startups. Legal startups and spin-offs began to appear in the Former Soviet Union in the late 1980s and rapidly expanded when Russia began instituting economic reforms in the early 1990s (Aslund, 1997). Thus, our NEWENT measure is intended to capture the accumulated regional "stock" of legal entrepreneurial activity.

\footnotetext{
${ }^{2}$ Below the $30 \%$ cutoff, there are regions such as Vologda and Kemerovo in which capital cities have smaller populations than other cities in the region. There are also regions such as the Sakha Republic that have low population densities and small urban sectors throughout the region. In either case, capital-city data are likely to be relatively uninformative about the region as a whole.
} 
GROWTH and NEWENT are listed in Table 1, and plotted in Figure 1a (along with the fitted line obtained by regressing GROWTH on a constant and NEWENT). A striking aspect of the figure is the wide range of growth experiences observed in our sample. Also notable is the correspondence observed between regional growth and new enterprise formation. The unconditional correlation between the series is 0.64 , and the estimated regression coefficient implies that the addition of a single new small enterprise per thousand inhabitants corresponds with a 1.07 percentage-point increase in the regional annual growth rate (statistically significant at the 5-percent level). Figure $1 \mathrm{~b}$ plots growth against new enterprises for a sub-sample of our data set that excludes three potential outliers (Moscow, St. Petersburg, and the oil-rich Tyumen oblast). These regions benefited from unusually high levels of new enterprise formation, and also enjoyed above-average growth. Their exclusion reduces the unconditional correlation between the series to 0.3 , but reduces the estimated regression coefficient only slightly, to 0.83 (the coefficient remains significant at the 5-percent level). We give special attention to these potential outliers in our empirical analysis, but our findings turn out not to be sensitive to their inclusion in the sample.

\section{2b. Policy reform}

We measure the extent of regional price liberalization (PRICE) using an official survey of a basket of 73 food goods that was conducted in capital cities in October 1995 (see European Union 1996). In the survey, each good was coded for its regulation type, including allocation by rationing and the issuance of coupon (most conservative); sales subject to price ceilings (medium regulation); prices subject to indirect controls such as subsidies and limits on price mark-ups (light regulation), and no price controls. The survey tallied points for the extent of price 
regulation on each product and ranks each region. We rank regions on a uniform unit scale from most regulated (1/48) to most liberal (1).

We measure small-scale privatization (SPRIV) and large-scale privatization (LPRIV) within each region using the accumulated number firms privatized by local and federal governments during 1993-1995 per thousand inhabitants. These measures potentially overstate privatization because they do not account for privatized enterprises that were subsequently nationalized or bankrupted. Fortunately, there was very little bankruptcy and nationalization in Russia between 1993 and 1995.

The final measure of regional policy reform we analyze is the share of the popular vote garnered by "pro-reform parties" in Russia's December 1995 parliamentary elections (REF). In this election, pro-reform parties stood for a continuation and deepening of microeconomic reforms, including price liberalization, privatization initiatives and protection of property rights. In contrast, non-reform parties called for a slowdown or even a reversal in price decontrol, privatization and property right protections (the category "pro-reform" is taken from Clem and Craumer, 2000). Our use of this measure was inspired by Warner's (1999) finding that regions that had implemented relatively widespread and deep microeconomic reforms prior to the election subsequently supported pro-reformist parties in the election. Thus REF serves as a proxy variable used to capture reformist activity that we do not measure directly. All four policy reform measures are listed in Appendix Table A1.

\section{2c. Initial conditions}

Our primary focus is on the relationship between growth, new enterprise formation and policy reform. However, in order to control for the influence of other relevant factors, we also consider five regional initial conditions (also listed in Appendix Table A1). 
The first initial condition we consider is the share of the population fifteen years old and higher as of 1994 that received formal schooling beyond the high-school level (EDU), which is taken from the 1994 Russian micro-census (Goskomstat, 1995a). Higher education is important in post-transition Russia, since workers and managers were expected to rapidly adjust to massive changes in market conditions.

Second, we consider initial living standards (INTIAL), which we measure using the ratio of average money income per capita to the cost of a uniform basket of 19 basic food goods; the average was computed between December of 1993 and March of 1994. Because food accounted for more than half of household expenditures during the 1990s (see Goskomstat 2000, p.167), INITIAL is a useful regional measure of per capita purchasing power. A positive (negative) correspondence between GROWTH and INITIAL indicates a divergence (convergence) in real income across regions.

Third, we consider initial production potential (IO), which is measured using labor shares employed in the industrial sectors within each region in 1985 (this is taken from Gaddy, 1996). We multiplied these shares by the industry's value added, net of labor costs (intermediate shadow-profit rate based on world-market prices and computed by Senik-Leygonie and Hughes, 1992), and summed the resulting products to compute IO. IO is meant to characterize the basic industrial structure of the region prior to transition: a high value indicates the regional presence of relatively competitive industries (e.g., oil and gas production). It is not surprising that the oil and gas industries have the highest value added in the industrial sectors, while food processing has the lowest (indeed, negative) value added. Because an industrial structure that is competitive on world markets is advantageous under market conditions, we would expect a positive correspondence between IO and GROWTH. 
Fourth, we measure the regional importance of the defense industry (DEFENSE) prior to transition. This measure is taken from Gaddy (1996); it is the number of workers employed in the defense industry per thousand employed workers in the region in 1985. Gaddy argues that the defense industry should have a positive impact on growth because it attracted highly skilled workers and gave regions strong political connections with major power brokers in Moscow. We expect DEFENSE to have a positive relationship with GROWTH, given the relative stability of this industry in an otherwise turbulent economic environment.

Finally, we measure the natural log of the distance of each region from Moscow (LNDIST). Moscow is the major source of financial and physical infrastructure within Russia, and has the most advanced human-capital stock. Thus distance from Moscow is a potentially useful measure of regional isolation (we thank an anonymous referee for suggesting the use of this variable).

\section{Results}

In quantifying the relationship between initial conditions, policy reform, new enterprise formation, and growth, special care was given to two issues: potential simultaneity between new enterprise formation and growth; and the potential impact of the three "outlier" regions on our analysis. To deal with the latter issue, we conducted our analysis with and without the inclusion of these three regions. ${ }^{3}$ As we illustrate below, the inclusion of these regions has a negligible impact on our results, so we report in full only those results obtained using the full data set. We deal with potential simultaneity by using a two-stage least squares (2SLS) estimation procedure.

\footnotetext{
${ }^{3}$ Note from Appendix Table A1 that Magadan is an outlier region for both LPRIV and SPRIV, which are roughly 4.67 and 5.5 standard deviations above average. We also examined the impact of dropping Magadan from the sample, and found that this had no impact on our results.
} 
We begin our analysis by regressing GROWTH on each of the additional variables included in our data set using ordinary least squares (OLS). The resulting estimates are reported in Table 2. (Standard errors reported throughout the paper are heteroskedasticity consistent, following White, 1980.) The $\mathrm{R}^{2}$ statistic we obtain in this regression is 0.502 , indicating that our variables have reasonably high explanatory power in accounting for regional variations in growth. Despite this, only two of the coefficients estimated in this regression are statistically significant at the $10 \%$ level: those associated with DEFENSE (with a p value of 0.03) and NEWENT (0.007). Two additional variables have marginally significant coefficients: IO (p value of 0.156) and PRICE ( $\mathrm{p}$ value of 0.142). (A discussion of quantitative significance accompanies the presentation of our 2SLS estimates below.)

We draw two preliminary conclusions from these OLS results. First, with the exception of our price liberalization, industrial organization and defense measures, reform policies and initial conditions appear to exhibit little direct correspondence with subsequent growth. Second, it appears that the remaining variables are potentially excludable from the growth regression in a 2SLS framework. Further support of this second conclusion is provided below.

We next conduct a 2SLS analysis in which we obtain fitted values of NEWENT in a firststage regression, and then combine these fitted values with the variables IO, DEFENSE and PRICE in a second-stage growth regression. The estimates we obtain are reported in Table 3.

Consider first the NEWENT regression. The $\mathrm{R}^{2}$ statistic of 0.819 indicates that the variables we use as instruments provide a good characterization of NEWENT. The coefficients on LNDIST, IO, DEFENSE, PRICE and SPRIV are statistically insignificant, but the remaining variables each appear to have a significant relationship with NEWENT, both statistically (at the $5 \%$ level) and quantitatively. To characterize quantitative significance, we report the impact on 
NEWENT of a one-standard-deviation increase in each variable in the last column of Table 3. For example, a one-standard-deviation increase in initial income (representing an $79 \%$ increase in the purchasing power of money income per capita, as reported in the sixth column of Table 3) corresponds with an additional 0.579 new enterprises per 1000 inhabitants on average across regions. Corresponding figures for education, reformist voting and large-scale privatization are $1.323,0.826$, and 0.443 .

Consider next the second-stage growth regression. The $\mathrm{R}^{2}$ statistic we obtain in this case is 0.491 , thus we observe a trivial deterioration in fit relative to the OLS results reported in Table 2. Our measure of price liberalization remains marginally significant in this case, with a $p$ value of 0.158. However, the quantitative significance of this variable is substantial: a one-standarddeviation increase corresponds with an additional annual growth rate of $0.671 \%$. The quantitative significance of IO and DEFENSE are also substantial (0.688\% and $0.93 \%)$, and their coefficients are each statistically significant at the $10 \%$ level. Finally, the coefficient estimated for the fitted value of NEWENT is 1.04 , and has a corresponding t statistic of nearly 4 . In this case, a one-standard-deviation increase represents an additional 2.374 additional new enterprises per 1000 inhabitants on average across regions, and corresponds with an additional annual growth rate of $2.469 \%$.

Note that since the coefficient estimated for NEWENT in the second-stage growth regression is approximately 1 , it is easy to calculate the indirect relationship between the variables used as instruments in the NEWENT regression and growth. For example, a onestandard-deviation increase in the large-scale privatization measure corresponds with an additional 0.443 new enterprises per 1000 inhabitants, which in turn corresponds with an additional annual growth rate of $1.04 \times 0.443=0.46 \%$. Thus while there does not appear to be a 
direct relationship between large-scale privatization and growth, there does seem to be a significant indirect relationship, operating through the influence of large-scale privatization on new enterprise formation. A similar observation holds for the reformist voting proxy.

The 2SLS estimates reported in Table 3 are of course based on identifying restrictions; the restrictions involve the exclusion of LNDIST, INITIAL, EDU, REF, LPRIV, and SPRIV from the second-stage growth regression. To evaluate the validity of these restrictions, we introduced each previously excluded variable - one at a time - in the second-stage regression, and then tested the null hypothesis that the coefficient on the newly included variable in the growth regression is zero using a simple t test. Results of this exercise are reported in Table 4. Note that the null hypothesis is not rejected for any of the six variables used as instruments: the smallest $\mathrm{p}$ value we obtain is 0.478 , for the reformist voting proxy. The quantitative significance of this variable is non-trivial (a one-standard-deviation increase corresponds with an additional annual growth rate of $0.607 \%$ ), but there is considerable imprecision associated with this estimate. A similar observation holds for the education measure (-0.586), while the quantitative significance of the remaining variables is negligible by comparison. Thus there is reasonable empirical support for the identifying assumptions upon which the results of Table 3 are based.

We conclude our analysis with an assessment of the influence of the "outlier" regions. This is done graphically in Figure 2, which illustrates the fitted relationship between new enterprise formation and growth derived using the 2SLS procedure described above for both the full data set (Figure 2a) and the subset obtained by excluding the three "outlier" regions (Figure 2b). Depicted values for new enterprise formation are the fitted values obtained from the firststage regressions, and depicted values for growth are residuals obtained by regressing growth on the variables besides new enterprise formation included in the second-stage growth regression. 
The results obtained using the full data set and the subsample are quite similar. Specifically, the coefficient estimated for NEWENT in the subsample is 1.414 (compared with 1.04 in the full data set), and has a $\mathrm{p}$ value of 0.015 . Since the standard deviation of the fitted version of NEWENT is only 0.977 in the subsample (compared with 2.374 in the full sample), this estimate actually yields a reduced value of the quantitative significance measure $(1.381 \%$, compared with $2.469 \%$ in the full sample). Nevertheless, the quantitative significance of new enterprise formation remains striking. The quantitative significance of the policy variables is also similar in the subsample. Specifically, one-standard-deviation increases in price liberalization, reformist voting and large-scale privatization correspond with additional annual growth rates of $0.46 \%, 0.75 \%$, and $0.35 \%$, compared with $0.671 \%, 0.884 \%$, and $0.47 \%$ in the full sample.

\section{Conclusion}

We have found that regional differences in the implementation of policy reforms help account in part for the striking regional variation in growth experiences observed in Post-Soviet Russia. Specifically, price-liberalization reforms exhibit a direct positive relationship with growth, while the relationship between large-scale regional privatization activity (as well as patterns of reformist voting) and growth is indirect, with new enterprise formation serving as a critical link.

We noted in the introduction that many cross-country studies have explored links between policy reform packages and growth in transition economies. The case of Russia suggests that generalizations based on aggregate observations should be interpreted with caution, given 
the extraordinary heterogeneity in policy reform packages and economic performance observed in Russia at the regional level. 


\section{REFERENCES}

Aslund, A., 1997, Observations on the development of small private enterprises in Russia, PostSoviet Geography and Economics 38, 191-206.

Berkowitz, D. and D.N. DeJong, 2001, Accounting for post-soviet Russia's economic growth, forthcoming in Regional Science and Urban Economics.

Berkowitz, D. and J. Holland, 2001, Does privatization enhance or deter small enterprise formation, forthcoming in Economics Letters.

Black, B., R. Kraakman, and A. Tarassova, 2000, Russian privatization and corporate governance: What went wrong? Stanford Law Review 52, 1731-1808.

Boycko, M., A. Shlefier, and R. Vishny, 1995, Privatizing Russia (MIT Press, Cambridge).

Carlin, W., S. Fries, M.E. Schaffer and P. Seabright, 2001, Competition and enterprise performance in transition economies: Evidence from a cross-country survey, Center for Economic Policy Research, Discussion Paper Series 2840.

Clem, R. and P. Craumer, 2000, Regional patterns of political preference in Russia: The December 1999 Duma elections, Post-Soviet Geography and Economics 51, 1-29. 
de Melo, M. and A. Gelb, 1996, A comparative analysis of twenty-eight transition economies in Europe and Asia, Post-Soviet Geography and Economics 37, 265-285.

de Melo, M., C. Denizer and A. Gelb, 1996, Patterns of transition from plan to market, World Bank Economic Review 10(3), 397-424.

European Union's TACIS Program, 1996, Analysis of tendencies of Russia’s regions, Contract BIS/95/321/057, Moscow, March.

Fisher, S., R. Sahay, and A. Gelb, 1996, Economies in transition: The beginnings of growth, American Economic Review May (Papers and Proceedings) 86(2), 229-233.

Friebel, G., 1995, Organizational issues in the Russian trade and service privatization, Economic Systems 19, 25-58.

Gaddy, C., 1996, The Price of the past, (Brookings Institute: Washington, DC).

Goskomstat Rossii, 1995a, Obrazovanie Nasilenie Rossii (po dannim mikroperepisi nasileniya 1994 g.), Goskomstat Rossii, Moscow.

Goskomstat Rossii, 1996, 2000, Rossiyskiy Statisticheskii Yezhegodnik. Goskomstat Rossii, Moscow. 
Goskomstat Rossii, 1993, 1994, 1995b, 1997, 1998, Sotsial'noe Ekonomicheskoye Polozhenie Rossii, Goskomstat Rossii, Moscow.

Johnson, S., D. Kaufmann and A. Shleifer, 1997, The unofficial economy in transition, Brookings Papers on Economic Activity 2, 159-240.

Kornai, J., 1990, The road to a free economy shifting from a Socialist system: The example of Hungary, (W.W. Norton, New York).

Lau, L., Y. Qian and G. Roland, 2000, Reform without losers: An interpretation of China's dualtrack approach to reforms, Journal of Political Economy 108(1), 120-163.

McMillan, J., 1997, Markets in transition, in: D.M. Kreps and K.F. Wallis, eds., Advances in economics and econometrics, (Cambridge University Press, Cambridge), 210-239.

Murphy, K., A. Shleifer and R. Vishny, 1992, The transition to a market economy: Pitfalls of partial reform, Quarterly Journal of Economics 107, 889-906.

Roland, G., 2000, Transition and economics: Politics, markets and firms, (MIT Press, Cambridge).

Sachs, J.D., 1997, The transition at mid decade, American Economic Review May (Papers and Proceedings), 86(2), 128-133. 
Selowsky, M. and R. Martin, 1997, Policy performance and output growth in transition economies, American Economic Review, May (Papers and Proceedings) 87(2), 349-353.

Senik-Leygonie, C. and G. Hughes, 1992, Industrial profitability and trade among the former Soviet Republics, Economic Policy 15, 354-386.

Shleifer, A. and R. Vishny, 1994, Politicians and firms, Quarterly Journal of Economics 109, 995-1025.

Warner, A. 1999, Is economic reform popular at the polls: Russia 1995? revised mimeo dated May 1997, Harvard Institute for International Development and Center for International Development, Harvard University.

White, H., 1980, A heteroskedasticity-consistent covariance matrix estimator and direct test for heteroskedasticity, Econometrica 48, 817-838. 


\section{Table 1: Growth and New Enterprise Formation}

\begin{tabular}{|c|c|c|c|}
\hline Region & Geographic Territory & GROWTH & NEWENT \\
\hline Karelian Republic & Northern & $-5.47 \%$ & 4.59 \\
\hline Murmansk Oblast & & $-6.10 \%$ & 4.87 \\
\hline St. Petersburg & Northwestern & $1.48 \%$ & 12.31 \\
\hline Kaliningrad Oblast & & $-2.46 \%$ & 4.08 \\
\hline Novgorod Oblast & & $0.91 \%$ & 4.44 \\
\hline Bryansk Oblast & Central & $-9.02 \%$ & 2.97 \\
\hline Ivanovo Oblast & & $0.37 \%$ & 3.95 \\
\hline Kaluga Oblast & & $-4.65 \%$ & 5.74 \\
\hline Kostroma Oblast & & $-5.23 \%$ & 3.23 \\
\hline Moscow & & $15.74 \%$ & 16.61 \\
\hline Oryol Oblast & & $-6.42 \%$ & 2.52 \\
\hline Ryazan Oblast & & $-7.12 \%$ & 3.70 \\
\hline Smolensk Oblast & & $0.60 \%$ & 2.47 \\
\hline Tula Oblast & & $-2.03 \%$ & 3.47 \\
\hline Yaroslavl Oblast & & $-2.02 \%$ & 4.89 \\
\hline Mariy-El Republic & Volga-Vyatka & $-6.47 \%$ & 2.09 \\
\hline Mordovian Republic & & $-6.07 \%$ & 1.88 \\
\hline Chuvash Republic & & $-7.48 \%$ & 3.09 \\
\hline Kirov Oblast & & $-1.50 \%$ & 1.96 \\
\hline Nizhniy Novgorod Oblast & & $-2.67 \%$ & 2.39 \\
\hline Voronezh Oblast & Central Black-Earth & $-2.82 \%$ & 3.08 \\
\hline Kursk Oblast & & $-5.51 \%$ & 1.71 \\
\hline Lipetsk Oblast & & $-4.70 \%$ & 2.40 \\
\hline Tatarstan Republic & Volga Region & $-1.30 \%$ & 4.23 \\
\hline Astrakhan Oblast & & $-2.71 \%$ & 4.18 \\
\hline Volgograd Oblast & & $2.66 \%$ & 6.14 \\
\hline Penza Oblast & & $-4.60 \%$ & 3.91 \\
\hline Samara Oblast & & $2.35 \%$ & 4.74 \\
\hline Saratov Oblast & & $-5.13 \%$ & 3.80 \\
\hline Ulyanovsk Oblast & & $-0.97 \%$ & 2.54 \\
\hline Adygey Republic & North Caucasus & $-7.85 \%$ & 4.00 \\
\hline Kabardin-Balkar Republic & & $0.58 \%$ & 4.05 \\
\hline North Osetian Republic & & $2.28 \%$ & 2.56 \\
\hline Bashkortostan Republic & Urals & $-0.96 \%$ & 3.12 \\
\hline Udmurt Republic & & $1.76 \%$ & 3.72 \\
\hline Kurgan Oblast & & $-5.02 \%$ & 2.79 \\
\hline Perm Oblast & & $3.80 \%$ & 3.42 \\
\hline Sverdlovsk & & $0.39 \%$ & 5.08 \\
\hline Chelyabinsk Oblast & & $5.20 \%$ & 3.09 \\
\hline Novosibirsk Oblast & Western Siberia & $1.93 \%$ & 5.20 \\
\hline Omsk Oblast & & $0.87 \%$ & 3.86 \\
\hline Tomsk Oblast & & $-2.46 \%$ & 4.17 \\
\hline Tyumen Oblast & & $4.65 \%$ & 9.40 \\
\hline Buryat Republic & Eastern Siberia & $-4.16 \%$ & 3.89 \\
\hline Primorskiy Kray & Far East & $-2.25 \%$ & 5.01 \\
\hline Khabarovsk Kray & & $-7.12 \%$ & 3.69 \\
\hline Kamchatka Oblast & & $-0.99 \%$ & 7.06 \\
\hline Magadan Oblast & & $1.95 \%$ & 7.36 \\
\hline Average & & $-1.79 \%$ & 4.36 \\
\hline Median & & $-2.14 \%$ & 3.88 \\
\hline Standard deviation & & $4.44 \%$ & 2.63 \\
\hline Minimum & & $-9.02 \%$ & 1.71 \\
\hline Maximum & & $15.74 \%$ & 16.61 \\
\hline
\end{tabular}


Table 2: Growth Regression, OLS

\begin{tabular}{|c|c|c|c|c|}
\hline Explanatory Variable & $\begin{array}{c}\text { Coefficient } \\
\text { Estimate }\end{array}$ & $\begin{array}{c}\text { Standard } \\
\text { Error }\end{array}$ & t statistic & p value \\
\hline Constant & -10.844 & 5.542 & -1.957 & 0.050 \\
\hline Distance (log) & 0.094 & 0.437 & 0.215 & 0.830 \\
\hline Initial Income & 0.226 & 0.630 & 0.360 & 0.719 \\
\hline IO & 0.046 & 0.033 & 1.419 & 0.156 \\
\hline Defense & 0.078 & 0.036 & 2.171 & 0.030 \\
\hline Education & -0.080 & 0.216 & -0.373 & 0.709 \\
\hline Reformist Voting & 0.055 & 0.082 & 0.663 & 0.507 \\
\hline Price Liberalization & 2.548 & 1.737 & 1.467 & 0.142 \\
\hline Large-Scale Privatization & -0.868 & 8.198 & -0.106 & 0.916 \\
\hline Small-Scale Privatization & -0.850 & 2.602 & -0.327 & 0.744 \\
\hline New Enterprise Formation & 0.992 & 0.369 & 2.688 & 0.007 \\
\hline$R^{2}: 0.502$ & & & & \\
\hline
\end{tabular}

Note: Standard errors are heteroskedasticity consistent (White, 1980). 
Table 3: Two-Stage Least-Squares Estimates

New-Enterprise Regression

\begin{tabular}{|c|c|c|c|c|c|c|}
\hline $\begin{array}{c}\text { Explanatory } \\
\text { Variable }\end{array}$ & $\begin{array}{c}\text { Coefficient } \\
\text { Estimate }\end{array}$ & $\begin{array}{c}\text { Standard } \\
\text { Error }\end{array}$ & t statistic & $p$ value & $\begin{array}{c}\text { Standard } \\
\text { Deviation of } \\
\text { Variable } \\
\end{array}$ & $\begin{array}{l}\text { Quantitative } \\
\text { Significance }\end{array}$ \\
\hline Constant & -4.378 & 1.780 & -2.460 & 0.014 & 0.000 & 0.000 \\
\hline $\begin{array}{c}\text { Distance } \\
(\log )\end{array}$ & -0.136 & 0.162 & -0.838 & 0.402 & 1.434 & -0.195 \\
\hline Initial Income & 0.733 & 0.341 & 2.148 & 0.032 & 0.790 & 0.579 \\
\hline 10 & -0.002 & 0.011 & -0.174 & 0.862 & 14.439 & -0.028 \\
\hline Defense & 0.002 & 0.012 & 0.194 & 0.846 & 12.982 & 0.030 \\
\hline Education & 0.312 & 0.053 & 5.927 & 0.000 & 4.243 & 1.323 \\
\hline $\begin{array}{l}\text { Reformist } \\
\text { Voting }\end{array}$ & 0.091 & 0.021 & 4.315 & 0.000 & 9.088 & 0.826 \\
\hline $\begin{array}{c}\text { Price } \\
\text { Liberalization }\end{array}$ & 0.473 & 0.639 & 0.740 & 0.459 & 0.292 & 0.138 \\
\hline $\begin{array}{l}\text { Large-Scale } \\
\text { Privatization }\end{array}$ & 5.431 & 2.691 & 2.018 & 0.044 & 0.082 & 0.443 \\
\hline $\begin{array}{l}\text { Small-Scale } \\
\text { Privatization }\end{array}$ & -0.359 & 0.861 & -0.417 & 0.676 & 0.241 & -0.087 \\
\hline$R^{2}: 0.819$ & & & & & & \\
\hline
\end{tabular}

Growth Regression

\begin{tabular}{|c|c|c|c|c|c|c|}
\hline $\begin{array}{c}\text { Explanatory } \\
\text { Variable } \\
\end{array}$ & $\begin{array}{c}\text { Coefficient } \\
\text { Estimate } \\
\end{array}$ & $\begin{array}{c}\text { Standard } \\
\text { Error } \\
\end{array}$ & t statistic & $p$ value & $\begin{array}{c}\text { Standard } \\
\text { Deviation of } \\
\text { Variable } \\
\end{array}$ & $\begin{array}{l}\text { Quantitative } \\
\text { Significance }\end{array}$ \\
\hline Constant & -9.532 & 1.446 & -6.592 & 0.000 & 0.000 & 0.000 \\
\hline 10 & 0.048 & 0.029 & 1.652 & 0.099 & 14.439 & 0.688 \\
\hline Defense & 0.072 & 0.034 & 2.113 & 0.035 & 12.982 & 0.930 \\
\hline $\begin{array}{c}\text { Price } \\
\text { Liberalization }\end{array}$ & 2.301 & 1.631 & 1.411 & 0.158 & 0.292 & 0.671 \\
\hline $\begin{array}{l}\text { New Enterprise } \\
\text { Formation } \\
\text { (fitted) }\end{array}$ & 1.040 & 0.261 & 3.981 & 0.000 & 2.374 & 2.469 \\
\hline$R^{2}: 0.491$ & & & & & & \\
\hline
\end{tabular}

Notes: Standard errors are heteroskedasticity consistent (White, 1980). Quantitative significance denotes the impact on the dependent variable of a one-standard-deviation increase in the explanatory variable. 


\section{Table 4: Exclusion Restrictions}

Full Sample

\begin{tabular}{|c|c|c|c|c|c|c|}
\hline $\begin{array}{c}\text { Explanatory } \\
\text { Variable }\end{array}$ & $\begin{array}{c}\text { Coefficient } \\
\text { Estimate }\end{array}$ & $\begin{array}{c}\text { Standard } \\
\text { Error }\end{array}$ & t statistic & p value & $\begin{array}{c}\text { Standard } \\
\text { Deviation of } \\
\text { Variable }\end{array}$ & $\begin{array}{c}\text { Quantitative } \\
\text { Significance }\end{array}$ \\
\hline $\begin{array}{c}\text { Distance } \\
\text { (log) }\end{array}$ & 0.048 & 0.420 & 0.115 & 0.909 & 1.434 & 0.069 \\
\hline $\begin{array}{c}\text { Initial } \\
\text { Income }\end{array}$ & 0.232 & 0.632 & 0.367 & 0.714 & 0.790 & 0.183 \\
\hline Education & -0.138 & 0.243 & -0.567 & 0.571 & 4.243 & -0.586 \\
\hline $\begin{array}{c}\text { Reformist } \\
\text { Voting }\end{array}$ & 0.067 & 0.094 & 0.709 & 0.478 & 9.088 & 0.607 \\
\hline $\begin{array}{c}\text { Large-Scale } \\
\text { Privatization }\end{array}$ & -2.311 & 4.263 & -0.542 & 0.588 & 0.082 & -0.188 \\
\hline $\begin{array}{c}\text { Small-Scale } \\
\text { Privatization }\end{array}$ & -0.622 & 1.400 & -0.444 & 0.657 & 0.241 & -0.150 \\
\hline
\end{tabular}

Notes: Exclusion restrictions were tested by dropping each of the indicated explanatory variables, one at a time, as an instrument for new enterprise formation, including the variable in the 2SLS growth regression, and testing the null hypothesis that the corresponding coefficient is zero. Standard errors are heteroskedasticity consistent (White, 1980). Quantitative significance denotes the impact on growth of a one-standard-deviation increase in the explanatory variable. 
Appendix Table A1: Regional Policy, Population Characteristics and Initial Conditions

\begin{tabular}{|c|c|c|c|c|c|c|c|c|c|}
\hline Region & PRICE & LPRIV & SPRIV & \multirow{2}{*}{$\begin{array}{c}\text { REFORM } \\
\begin{array}{c}\text { Dec-95 } \\
\%\end{array} \\
\end{array}$} & \multirow{2}{*}{$\begin{array}{c}\text { EDU } \\
\begin{array}{c}1994 \\
\%\end{array}\end{array}$} & \multirow{2}{*}{$\begin{array}{c}\text { INITIAL } \\
\text { 1993:IV }\end{array}$} & \multirow{2}{*}{$\begin{array}{c}\mathrm{IO} \\
1985 \\
\%\end{array}$} & \multirow{2}{*}{$\begin{array}{c}\text { DEFENSE } \\
1985 \\
\text { per } 1000 \\
\text { workers } \\
\end{array}$} & \multirow{2}{*}{$\begin{array}{c}\text { DIST } \\
\text { From } \\
\text { Moscow } \\
(\mathrm{kms}) \\
\end{array}$} \\
\hline & $\begin{array}{l}\text { Oct-95 } \\
\text { ranking }\end{array}$ & \multicolumn{2}{|c|}{$\begin{array}{c}\text { Dec-95 } \\
\text { firms per } 1000 \text { citizens }\end{array}$} & & & & & & \\
\hline Karelia & 0.646 & 0.032 & 0.618 & 36.2 & 12.7 & 3.43 & 7.16 & 5.7 & 920 \\
\hline Murmansk & 0.438 & 0.051 & 0.261 & 38 & 15 & 3.79 & -13.38 & 4.3 & 1951 \\
\hline St. Petersburg & 0.500 & 0.140 & 0.038 & 54.1 & 29.5 & 2.65 & 7.50 & 34.4 & 646 \\
\hline Kaliningrad & 0.854 & 0.173 & 0.526 & 30.7 & 16.3 & 2.46 & -28.05 & 15.9 & 1264 \\
\hline Novgorod & 0.771 & 0.126 & 0.556 & 30.5 & 11.5 & 2.51 & 7.30 & 39.2 & 602 \\
\hline Bryansk & 0.292 & 0.056 & 0.333 & 18.9 & 10.8 & 2.66 & 5.04 & 36 & 405 \\
\hline Ivanovo & 0.708 & 0.250 & 0.327 & 24.5 & 12.3 & 1.75 & 21.13 & 1.7 & 320 \\
\hline Kaluga & 0.167 & 0.155 & 0.383 & 28.5 & 14.6 & 2.74 & 1.60 & 46.9 & 183 \\
\hline Kostroma & 1.000 & 0.167 & 0.284 & 24.4 & 11.7 & 2.56 & 6.49 & 13.8 & 377 \\
\hline Moscow & 0.979 & 0.065 & 0.260 & 57.3 & 33.4 & 4.60 & 8.36 & 24.4 & 0 \\
\hline Oryol & 0.021 & 0.103 & 0.187 & 16.7 & 12.7 & 4.04 & 8.27 & 13 & 382 \\
\hline Ryazan & 0.792 & 0.157 & 0.299 & 20.3 & 12.6 & 2.43 & 6.03 & 27.6 & 197 \\
\hline Smolensk & 0.229 & 0.116 & 0.370 & 18.9 & 12.3 & 2.47 & 7.66 & 21.1 & 419 \\
\hline Tula & 0.688 & 0.115 & 0.294 & 26.4 & 13 & 3.06 & 12.08 & 33.3 & 193 \\
\hline Yaroslavl & 0.333 & 0.125 & 0.434 & 35.2 & 13.3 & 2.86 & 12.66 & 22.3 & 282 \\
\hline Mariy-El & 0.458 & 0.061 & 0.218 & 20.9 & 13 & 2.63 & 1.59 & 45.7 & 913 \\
\hline Mordovia & 0.146 & 0.029 & 0.117 & 28.2 & 13.4 & 2.00 & 11.54 & 15.8 & 601 \\
\hline Chuvash & 0.188 & 0.019 & 0.237 & 22.9 & 12 & 2.16 & 12.69 & 19.9 & 768 \\
\hline Kirov & 0.750 & 0.108 & 0.346 & 22.8 & 10.7 & 2.54 & 3.79 & 31.4 & 909 \\
\hline Nizhni Nogorod & 0.479 & 0.128 & 0.326 & 31.9 & 13 & 2.76 & 11.02 & 32.4 & 444 \\
\hline Voponezh & 0.313 & 0.077 & 0.243 & 21.3 & 14.2 & 2.39 & -4.11 & 40.2 & 572 \\
\hline Kursk & 0.125 & 0.077 & 0.392 & 14.8 & 13.6 & 2.59 & 0.42 & 13.9 & 536 \\
\hline Lipetsk & 0.208 & 0.078 & 0.248 & 20.4 & 11.7 & 3.03 & 10.42 & 8.1 & 497 \\
\hline Tatarstan & 0.250 & 0.000 & 0.057 & 42.2 & 12.5 & 3.36 & 11.34 & 30.1 & 749 \\
\hline Astrakhan & 0.271 & 0.144 & 0.361 & 27.1 & 12.6 & 2.23 & -19.56 & 23.1 & 1882 \\
\hline Volgograd & 0.083 & 0.151 & 0.295 & 27.4 & 13.8 & 2.32 & 10.01 & 20.9 & 1068 \\
\hline Penza & 0.542 & 0.026 & 0.232 & 19 & 11.9 & 2.12 & 5.11 & 24.4 & 707 \\
\hline Samara & 0.896 & 0.067 & 0.306 & 30.1 & 15.7 & 2.65 & 11.79 & 34.2 & 1044 \\
\hline Saratov & 0.833 & 0.135 & 0.444 & 21.7 & 16.4 & 2.57 & 6.47 & 32.3 & 859 \\
\hline Ulyanovsk & 0.042 & 0.054 & 0.083 & 16.3 & 12.1 & 3.90 & 8.28 & 34.2 & 873 \\
\hline Adyegey & 0.625 & 0.076 & 0.195 & 18.4 & 11.5 & 2.10 & 16.95 & 4 & 1653 \\
\hline Karb. Balkar & 0.375 & 0.020 & 0.083 & 33.8 & 13.8 & 2.07 & 3.77 & 18.7 & 1866 \\
\hline North Ossetia & 0.813 & 0.026 & 0.008 & 12.9 & 18.7 & 1.87 & 3.04 & 33.1 & 1916 \\
\hline Bashkortostan & 0.104 & 0.000 & 0.155 & 26.1 & 10.6 & 2.98 & 14.00 & 28.8 & 1493 \\
\hline Udmurtia & 0.396 & 0.032 & 0.301 & 23.9 & 12.6 & 2.31 & 7.25 & 57 & 1119 \\
\hline Kurgan & 0.917 & 0.088 & 0.209 & 19.2 & 9.2 & 1.89 & 0.83 & 22.4 & 2038 \\
\hline Perm & 0.938 & 0.046 & 0.399 & 34.5 & 11 & 2.32 & 11.96 & 37.8 & 1389 \\
\hline Sverdlovsk & 0.583 & 0.118 & 0.466 & 34.4 & 12.3 & 2.94 & 16.08 & 32.5 & 1647 \\
\hline Chelyabinsk & 0.604 & 0.096 & 0.363 & 34.6 & 12 & 2.22 & 21.79 & 22.3 & 1909 \\
\hline Novosibirsk & 0.521 & 0.148 & 0.199 & 26.6 & 15.9 & 1.55 & 0.91 & 45.3 & 3182 \\
\hline Omsk & 0.063 & 0.116 & 0.188 & 22.5 & 13.3 & 3.07 & 5.45 & 42.5 & 2550 \\
\hline Tomsk & 0.958 & 0.171 & 0.405 & 31 & 18.2 & 2.78 & 8.27 & 12.8 & 3489 \\
\hline Tyumen & 0.667 & 0.254 & 0.280 & 27.5 & 13.1 & 6.00 & 15.02 & 13.2 & 1983 \\
\hline Buryatia & 0.354 & 0.049 & 0.506 & 21 & 16.2 & 2.28 & 4.71 & 21.8 & 5494 \\
\hline Primorskiy & 0.729 & 0.033 & 0.367 & 21.4 & 16.4 & 1.63 & -10.10 & 15.9 & 8896 \\
\hline Khabarovsk & 0.417 & 0.149 & 0.405 & 31.5 & 18.6 & 2.35 & 3.77 & 28.6 & 8087 \\
\hline Kamchatka & 0.875 & 0.104 & 0.630 & 40.1 & 16.7 & 3.24 & -71.64 & 2.5 & 11436 \\
\hline Magadan & 0.563 & 0.487 & 1.656 & 31.3 & 16.4 & 3.38 & 0.62 & 41.4 & 11736 \\
\hline Average & 0.51 & 0.104 & 0.331 & 27.5 & 14.3 & 2.71 & 4.24 & 25.6 & 1926 \\
\hline Median & 0.51 & 0.100 & 0.300 & 26.5 & 13.0 & 2.56 & 7.20 & 24.4 & 917 \\
\hline Standard Dev. & 0.29 & 0.082 & 0.241 & 9.1 & 4.2 & 0.79 & 14.44 & 13.0 & 2704 \\
\hline Minimum & 0.02 & 0.000 & 0.008 & 12.9 & 9.2 & 1.55 & -71.64 & 1.7 & 0 \\
\hline Maximum & 1.00 & 0.487 & 1.656 & 57.3 & 33.4 & 6.00 & 21.79 & 57.0 & 11736 \\
\hline
\end{tabular}



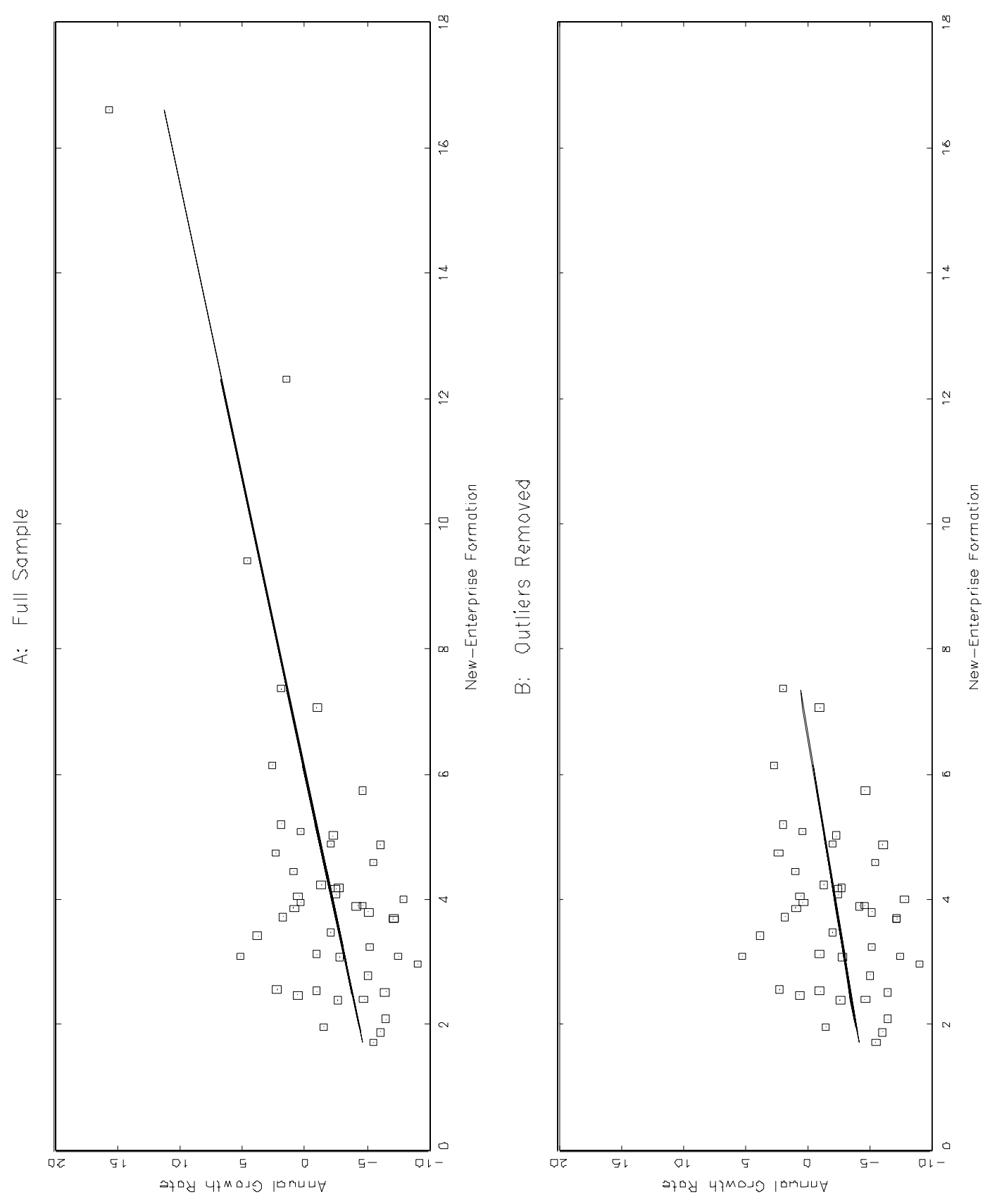
Figure 1: Two-Stage Least Squares Estimates

A: Full 5 ample

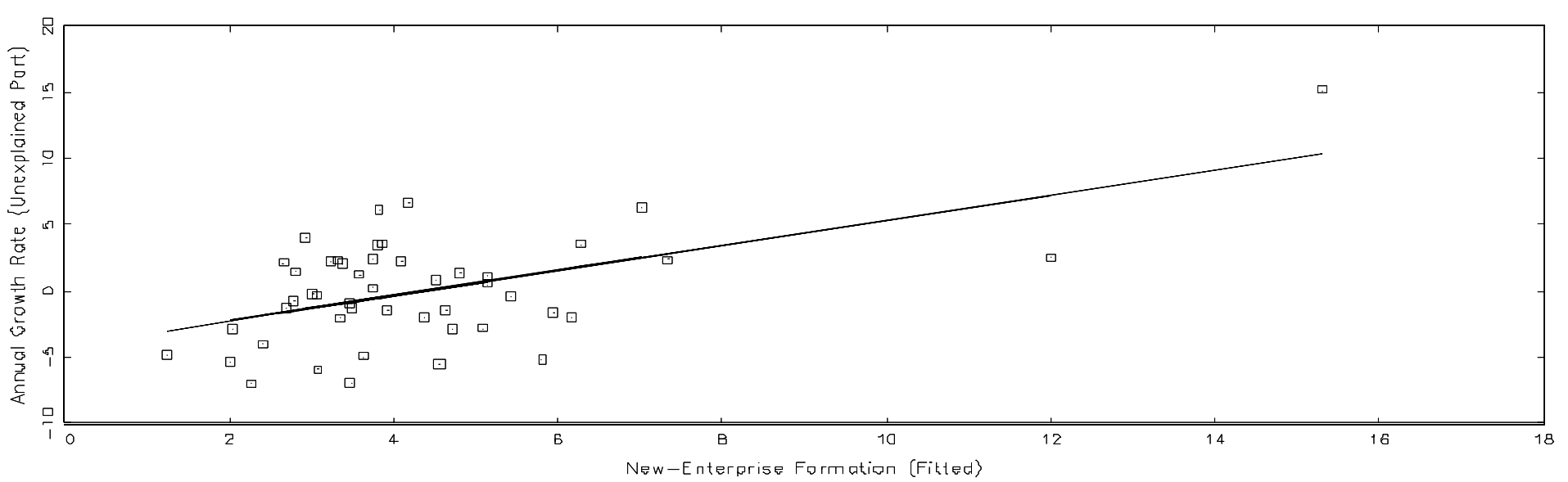

B: Outliers Remover

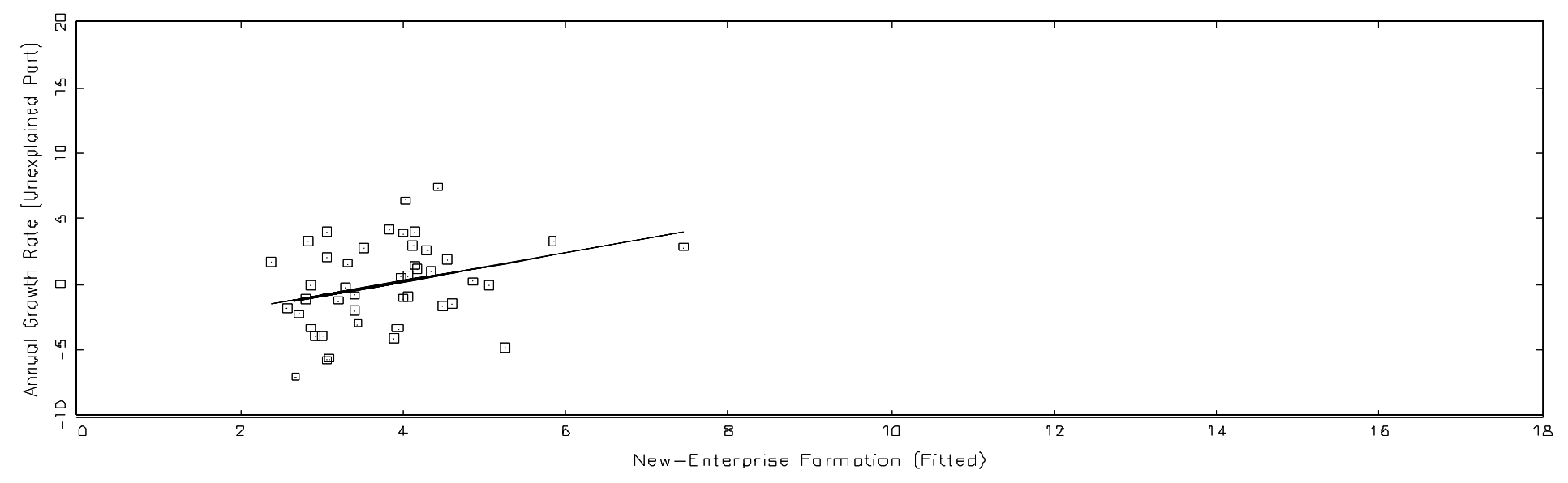




\section{DAVIDSON INSTITUTE WORKING PAPER SERIES - Most Recent Papers}

The entire Working Paper Series may be downloaded free of charge at: www.wdi.bus.umich.edu

CURRENT AS OF 11/29/01

\begin{tabular}{|c|c|c|}
\hline Publication & Authors & Date \\
\hline No. 405: Policy Reform and Growth in Post-Soviet Russia & $\begin{array}{l}\text { Daniel Berkowitz and David N. } \\
\text { DeJong }\end{array}$ & Oct. 2001 \\
\hline $\begin{array}{l}\text { No. 404: Social Policies and Structures: Institutional Frictions and Traps } \\
\text { in the Czech Republic after } 1989\end{array}$ & Jiří Večerník & Nov. 2001 \\
\hline $\begin{array}{l}\text { No. 403: Investment, Efficiency, and Credit Rationing: Evidence from } \\
\text { Hungarian Panel Data }\end{array}$ & Mathilde Maurel & Nov. 2001 \\
\hline $\begin{array}{l}\text { No. 402: Subduing High Inflation in Romania. How to Better Monetary } \\
\text { and Exchange Rate Mechanisms? }\end{array}$ & $\begin{array}{l}\text { Daniel Daianu and Radu } \\
\text { Vranceanu }\end{array}$ & Aug. 2001 \\
\hline $\begin{array}{l}\text { No. 401: The Gender Wage Gap in Bulgaria: A Semiparametric } \\
\text { Estimation of Discrimination }\end{array}$ & Dean Jolliffe & July 2001 \\
\hline $\begin{array}{l}\text { No. 400: Do External Auditors Perform a Corporate Governance Role in } \\
\text { Emerging Markets? Evidence from East Asia }\end{array}$ & Joseph P. H. Fan and T.J. Wong & Oct. 2001 \\
\hline $\begin{array}{l}\text { No. 399: Financial Conditions and Investment during the Transition: } \\
\text { Evidence from Czech Firms }\end{array}$ & Lubomír Lízal and Jan Svejnar & Oct. 2001 \\
\hline $\begin{array}{l}\text { No. 398: Accessible Pareto-Improvements: Using Market Information to } \\
\text { Reform Inefficiencies }\end{array}$ & Michael Mandler & May 2001 \\
\hline No. 397: The Making of an Integrated National Grain Market in China & Wubiao Zhou & Oct. 2001 \\
\hline No. 396: Corruption and Resource Allocation: Evidence from China & Wei Li & June 2001 \\
\hline $\begin{array}{l}\text { No. 395: Government Shareholding and the Value of China's Modern } \\
\text { Firms }\end{array}$ & Lihui Tian & Apr. 2001 \\
\hline No. 394: Labor Hoarding in Russia: Where Does it Come from? & $\begin{array}{l}\text { Rouslan Koumakhov and Boris } \\
\text { Najman }\end{array}$ & June 2000 \\
\hline $\begin{array}{l}\text { No. 393: Ownership Structure, Corporate Governance, And Firm Value: } \\
\text { Evidence from the East Asian Financial Crisis }\end{array}$ & Michael Lemmon and Karl Lins & Apr. 2001 \\
\hline No. 392: Marshall and Labour Demand in Russia: Going Back to Basics & $\begin{array}{l}\text { Jozef Konings and Hartmut } \\
\text { Lehmann }\end{array}$ & Aug. 2001 \\
\hline No. 391: Economic Transition and Elections in Poland & $\begin{array}{l}\text { John E. Jackson, Jacek Klich, and } \\
\text { Krystyna Poznańska }\end{array}$ & June 2001 \\
\hline $\begin{array}{l}\text { No. 390: Effects of Bank Insolvency and Strategic Uncertainty on } \\
\text { Corporate Restructuring in Transition Economies }\end{array}$ & Christa Hainz & Aug. 2001 \\
\hline No. 389: Mark-Up Pricing In Bulgarian Manufacturing & $\begin{array}{l}\text { Rumen Dobrinsky, Boyko } \\
\text { Nikolov, and Nikolay Markov }\end{array}$ & June 2001 \\
\hline $\begin{array}{l}\text { No. 388: Globalization and Firms' Financing Choices: } \\
\text { Evidence from Emerging Economies }\end{array}$ & $\begin{array}{l}\text { Sergio Schmukler and Esteban } \\
\text { Vesperoni }\end{array}$ & May 2001 \\
\hline $\begin{array}{l}\text { No. 387: The Distributional Impacts of Indonesia's Financial Crisis on } \\
\text { Household Welfare: A "Rapid Response" Methodology }\end{array}$ & $\begin{array}{l}\text { Jed Friedman and James } \\
\text { Levinsohn }\end{array}$ & Sept. 2001 \\
\hline $\begin{array}{l}\text { No. 386a: Corporate Financial Policies and Performance Around } \\
\text { Currency Crises }\end{array}$ & $\begin{array}{l}\text { Arturo Bris, Yrjö Koskinen, and } \\
\text { Vicente Pons }\end{array}$ & Oct. 2001 \\
\hline No. 385: Ownership and Productive Efficiency: Evidence from Estonia & Derek C. Jones and Niels Mygind & Aug. 2001 \\
\hline $\begin{array}{l}\text { No. 384: Forthcoming in: Journal of Economic Perspectives, } \\
\text { "Institutional Determinants of Labor Reallocation in Transition" Vol. } \\
\text { 16, No. 2, Feb. } 2002 \text {. }\end{array}$ & Tito Boeri and Katherine Terrell & June 2001 \\
\hline $\begin{array}{l}\text { No. 383: Deindustrialisation and Structural Change During the Post- } \\
\text { Communist Transition }\end{array}$ & $\begin{array}{l}\text { Tomasz Mickiewicz and Anna } \\
\text { Zalewska }\end{array}$ & June 2001 \\
\hline No. 382: Markets and Growth & Štěpán Jurajda and Janet Mitchell & July 2001 \\
\hline $\begin{array}{l}\text { No. 381: Labor Market Discrimination During Post-Communist } \\
\text { Transition: A Monopsony Approach to the Status of Latvia's Russian } \\
\text { Minority }\end{array}$ & Robert S. Chase & Sept. 2000 \\
\hline No. 380: Dollarization of Liabilities in Non-tradable Goods Sector & Frédéric Chabellard & June 2001 \\
\hline
\end{tabular}

